POIMEN : Jurnal Pastoral Konseling

ISSN (Print)

ISSN (Online)

http://ejournal-iakn-manado.ac.id/index.php/poimen Vol.1, No.1, pp. 1 - 67, Juni 2020
IAKN MANADO

FAKULTAS TEOLOGI

PRODI PASTORAL KONSELING

\begin{tabular}{|l|l|}
\hline Diterima & 17 Mei 2020 \\
\hline Disetujui & 29 Juni 2020 \\
\hline
\end{tabular}

\title{
LAYANAN KONSELING PASTORAL KEPADA PEREMPUAN YANG MELAKUKAN ABORSI DI DESA KALINAUN
}

\author{
Novita P. Sianturi \\ Institut Agama Kristen Negeri Manado, Email : novitapsianturi@gmail.com \\ Meifie E. Kasiadi \\ Institut Agama Kristen Negeri Manado, Email Email: ekklesiakasiadi18@gmail.co
}

\begin{abstract}
ABSTRAK
Tujuan dari penelitian ini adalah untuk mengetahui bagaimana pemahanan masyarakat tentang aborsi, faktor apa yang mendorong perempuan melakukan aborsi, dan bagaimana rancangan Konseling Pastoral yang akan dilakukan kepada subjek-subjek yang melakukan aborsi. Penelitian ini merupakan penelitian kualitatif dengan metode studi kasus yang dilaksanakan di Desa Kalinaun pada tahun 2019.

Dari hasil temuan tersebut maka direkomendasikan kiranya tokoh-tokoh agama melaksanakan perannya sebagai pelayan Tuhan di gereja khususnya ditengah-tengah jemaat bahkan di tengah-tengah masyarakat, sehingga adanya perubahan perilaku yang lebih baik dari subjek-subjek dalam membuat hidup para wanita muda menjadi lebih berarti, serta bagaimana pemerintah di Desa Kalinaun dapat bekerja sama dengan tokoh agama dalam membuat program berupa sosialisasi yang berhubungan dengan tindakan aborsi.
\end{abstract}

Kata Kunci : Pendampingan Pastoral, Perempuan Pelaku Aborsi

\begin{abstract}
This research is purposed to know the society comprehension about abortion, factors that motivate women did the abortion, and how the Pastoral Counseling that will be held to the abortion subjects. This research is a qualitative research by using the case study method that will be held in Kalinaun Village in 2019.

From that results above, we recommend to the religious figures to do role as God's servant in the church especially in the midst of the congregation even in the society, so that will be better behavior from the subjects that make the young women become more valuable, and how the government in Kalinaun Village can work together with the religious figures by making the program such as socialiszation about the abortion actions.
\end{abstract}

Keywords : Pastoral Care, Women Perpetrators of Abortio 


\section{A. PENDAHULUAN}

Tindakan aborsi merupakan salah satu isu yang menarik untuk dibahas, karena meskipun oleh hukum dilarang, tetapi aborsi tetap dilakukan. Data yang dihimpun Komnas Perlindungan Anak Indonesia (KPAI) menemukan dalam kurun waktu tiga tahun (2014-2016) kasus aborsi terus meningkat. Tahun 2014 ditemukan 2 juta jiwa anak korban aborsi, tahun berikutnya (2015) naik 300.000 menjadi 2,3 juta jani yang dibuang paksa. Sementara itu, pada tahun 2016 naik dari 200.000 menjadi 2,5 juta jiwa. 62,6 persen diantaranya adalah anak berusia dibawah 18 tahun. Metode aborsi 37 persen dilakukan melalui kuret, 25 persen melalui oral dan pijatan, 13 persen melalui cara suntik, 8 persen memasukkan benda asing ke dalam rahim dan selebihnya melalui jamu dan akupuntur. ${ }^{1}$

Dari hasil penelitian juga menemukan bahwa dalam setahun di Indonesia bisa terjadi 750 - 1.000 kasus aborsi yang disengaja walaupun aborsi itu sudah dilarang secara hukum. $^{2}$ Informasi tentang pengguguran atau aborsi dari Badan Penelitian dan Pengembangan Kesehatan dalam laporan Riskesdes 2015 kurun waktu lima tahun terakhir mengungkapkan bahwa Provinsi Sulawesi Utara mencapai angka 4,9\%, dengan variasi angka terendah 2,4\% yang terdapat di Provinsi Bengkulu dan angka tertinggi 6,9\% di Papua Barat. $^{3}$

Berdasarkan riset 2016 yang dikeluarkan Badan Koordinasi Keluarga Berencana Nasional (BKKBN), diperkirakan setiap tahun jumlah aborsi di Indonesia mencapai 2,5 juta jiwa dari 5 juta kelahiran pertahun 1,1 juta diantaranya tindakan aborsi disebabkan karena adanya alasan hamil di luar ikatan pernikahan. Bahkan, 800 ribu diantaranya adalah kalangan remaja. ${ }^{4}$ Tindakan aborsi saat hamil secara tidak diinginkan dari hasil analisisnya cukup mengkhawatirkan yaitu $6,4 \%$ di antara mereka mencoba aborsi namun gagal, sementara yang meneruskan kehamilannya ada 33\% serta sebanyak $58 \%$ yang hamil diluar nikah berupaya menggugurkan kandungannya atau memilih melakukan aborsi. 5

Perubahan peran dari seorang gadis menjadi seorang ibu dapat dialami secara normal oleh seorang perempuan yang mengalami kehamilan, hal ini akan dirasakan sebagai suatu peristiwa yang membahagiakan jika perubahan itu didukung dengan kesiapan fisik, psikologis ataupun spiritual. Namun sebaliknya dalam kehamilan diluar nikah dapat dikatakan dari berbagai segi biasanya belum memiliki kesiapan untuk terjadinya perubahan dalam dirinya bahkan mungkin untuk menerima kandungannya. Untuk itu situasi ini dapat memunculkan kecemasan yang cukup berat, karena adanya ketidak-siapan diri menghadapi kehamilannya, dan kecemasan itu akan berujung pada mencari jalan keluar dengan melakukan aborsi.

Tindakan aborsi ini menjadi masalah yang cukup serius karena ada sebagian dari masyarakat yang menganggap aborsi sebagai tindakan yang dapat menyelamatkan keluarga dari rasa malu. Namun demikian sebagian besar masyarakat juga menganggap bahwa aborsi sebagai tindakan pembunuhan dikarenakan janin atau bayi yang ada di dalam kandungan seorang ibu berhak untuk hidup yang wajar. Alasan yang paling utama aborsi adalah alasan non-medis di antaranya tidak ingin memiliki anak karena khawatir

\footnotetext{
${ }^{1}$ News Indonesia, Artikel, diakses pada 24 Januari 2019 pukul 17.00 WITA

2 Paulinus Soge, Hukum Aborsi Tinjauan Politik Hukum Pidana Terhadap Perkembangan Hukum di Indonesia, (Yogyakarta: Universitas Atmajaya, 2010), h.1

${ }^{3}$ Sadewo Frans, Kejadian Keguguran, Kehamilan Tidak Direncanakan dan Pengguguran di Indonesia, (Surabaya: Akademia, 2017), h.182

${ }^{4}$ https://www.bkkbn.go.id/category/artikel/data-aborsi-tahun-2016 diakses tanggal 14 Mei 201920.00 WITA

${ }^{5}$ Studi Kependudukan dan Kebijakan Universitas Gadjah Mada dan Badan Kependudukan dan Keluarga Berencana Nasional, 2016
} 
mengganggu karir, tidak cukup memiliki uang untuk merawat anak, dan tidak ingin melahirkan anak tanpa ayah.

Alasan lain yang sering dilontarkan adalah masih terlalu muda terutama mereka yang hamil di luar nikah, bahkan ada yang takut karena masih dalam jenjang pendidikan yang bisa membawa malu bagi diri mereka dan keluarga. Walaupun dalam berbagai alasan, ada keluarga yang tetap merahasiakan ketika tindakan aborsi yang berakibat pendarahan dan harus ditangani oleh rumah sakit. Alasan-alasan tersebut hanya menunjukkan ketidakpedulian seorang wanita, yang mementingkan dirinya sendiri tanpa memikirkan kehidupan janin yang dikandungnya hanya karena alasan bahwa tidak dalam ikatan perkawinan dan karena dalam pendidikan. Tapi bagaimana dengan perasaan mereka yang melakukan aborsi sampai beberapa kali dengan tidak ada perasaan bersalah dalam diri mereka, walaupun mereka sudah mengetahui ada kemungkinan aborsi akan dilakukan lagi di kehidupan mereka yang sedang berlanjut.

Fenomena ini juga terjadi pada beberapa perempuan di Desa Kalinaun, dimana dari hasil observasi awal menunjukkan bahwa ada perempuan-perempuan yang melakukan aborsi sampai beberapa kali dengan laki-laki yang berbeda-beda yang tidak ada hubungan ikatan pernikahan bahkan sampai sekarang tidak menunjukkan perasaan bersalah telah melakukan tindakan aborsi dan masih melakukan hal yang tidak dibenarkan oleh keluarga dan masyarakat sekitar, seperti menjalani hubungan gelap dengan suami orang lain, bahkan kadang sekali terlihat berada di rumah bersama keluarga. Ada juga yang menyesali tindakan aborsi yang dilakukannya sehingga ada perasaan bersalah yang berpengaruh pada perilakunya seperti tidak mau jika harus duduk bersama orang tuanya kecuali jika ada orang lain yang duduk bersama mereka, karena tindakan aborsi tidak diketahui oleh kedua orang tuanya karena masih dalam jenjang pendidikan, oleh karena itu peneliti terdorong untuk melakukan penelitian dengan judul "Layanan Konseling Pastoral Terhadap Perempuan Yang Melakukan Aborsi di Desa Kalinaun”.

Berdasarkan latar belakang masalah tersebut di atas, maka peneliti dapat merumuskan pokok permasalahan, yaitu: bagaimana pemahaman masyarakat Desa Kalinaun tentang tindakan aborsi ?, apa saja faktor yang mendorong tindakan aborsi di Desa Kalinaun, bagaimana keadaan para wanita setelah melakukan aborsi di Desa Kalinaun ?, bagaimana rancangan layanan Konseling Pastoral yang dapat dilakukan terhadap perempuan yang melakukan aborsi di luar ikatan pernikahan di Desa Kalinaun?

\section{B. DESKRIPSI TEORETIK}

\section{Aborsi}

Masalah aborsi sangat erat kaitannya dengan hak setiap individu dalam menjalani proses reproduksi dan kehidupan seksual yang sehat, aman, serta bebas dari paksaan. Di sisi lain, kondisi janin yang berada dalam kandungan juga berhak untuk terus hidup dan bertumbuh kembang. Jika aborsi yang dilakukan adalah tindakan kriminal tentu saja hal tersebut sangat bertentangan dengan ketentuan hukum di Indonesia. Sejalan dengan itu, akan diuraikan pengertian aborsi, faktor terjadinya aborsi dan hukum yang memmuat tentang aborsi.

Istilah aborsi dalam pengertian awam adalah penguguran kandungan, keluarnya hasil konsepsi atau pembuahan sebelum waktunya. Abortion dalam kamus Inggris Indonesia diterjemahkan dengan penguguran kandungan. ${ }^{6}$ Dalam Blaks 's Law Dictionary, kata abortion yang diterjemahkan menjadi aborsi dalam bahasa Indonesia mengandung arti: "The spontaneous or articially induced expulsion of an ambiro or featus. As used in

${ }^{6}$ Echols, dan Hassan Shaddily, Kamus Inggris Indonesia, (Jakarta: Gramedia, 2014), h.2 
illegal context refers to induced abortion". Dengan demikian, menurut Blak's Law Dictionary, keguguran dengan keluarnya embrio atau fetus tidak semata-mata karena terjadi secara alamiah, akan tetapi juga disengaja atau terjadi karena adanya campur tangan (provokasi) manusia. ${ }^{7}$ Ensiklopedi Indonesia memberikan penjelasan bahwa abortus diartikan sebagai pengakhiran kehamilan sebelum masa gestasi 28 minggu atau sebelum janin mencapai berat 100 gram. $^{8}$

Dalam pengertian medis, aborsi adalah terhentinya kehamilan dengan kematian dan pengeluaran janin pada usia kurang dari 20 minggu dengan berat janin kurang dari 500 gram, yaitu sebelum janin dapat hidup di luar kandungan secara mandiri. ${ }^{9}$ Menggugurkan kandungan atau dalam dunia kedokteran dikenal dengan istilah "aborsi", berarti pengeluaran hasil konsepsi (pertemuan sel telur dan sel sperma) sebelum janin dapat hidup di luar kandungan. Dari segi medis juga, tidak ada batasan pasti kapan kandungan bisa digugurkan. Kandungan perempuan bisa digugurkan kapan saja sepanjang ada indikasi medis untuk menggugurkan kandungan itu. Misalnya jika diketahui anak yang akan lahir mengalami cacat berat atau si ibu menderita penyakit jantung yang akan sangat berbahaya sekali untu keselamatan jiwanya pada saat melahirkan nanti. Sekalipun janin itu sudah berusia lima bulan atau enam bulan, pertimbangan medis membolehkan dilakukan abortus provocatus. ${ }^{10}$

Dari definisi-definisi di atas dapat disimpulkan bahwa aborsi atau pengguguran kandungan itu adalah suatu perbuatan yang sengaja mengakhiri kehamilan atau dilakukan sebelum waktunya melahirkan.

\section{Jenis-jenis Aborsi}

Banyak kejadian aborsi merupakan aborsi yang tidak aman, untuk itu dalam proses aborsi ada beberapa jenis aborsi yang dapat kita lihat, yaitu:

a. Spontan/alamiah (terjadi secara alami, tanpa tindakan apapun);

b. Buatan/sengaja (aborsi yang dilakukan secara sengaja);

c. Terapeutik/medis (aborsi yang dilakukan atas indikasi medis karena terdapatnya suatu permasalahan/komplikasi). ${ }^{11}$

Begitu pula di bawah ini diuraikan abortus yang secara medis dapat dibagi menjadi dua macam:

\section{a. Abortus Spontaneous}

Abortus spontaneous adalah aborsi yang terjadi dengan tidak didahului faktor-faktor mekanis ataupun medicinalis semata-mata disebabkan oleh faktor alamiah. Kehilangan janin tidak disengaja biasanya terjadi pada kehamilan usia muda (satu sampai tiga bulan). Ini dapat terjadi karena penyakit anatara lain: demam; panas tinggi, ginjal TBC, sipilis atau karena kesalahan genetik. Pada aborsi spontan tidak jarang janin keluar dalam keadaan utuh. ${ }^{12}$

\section{b. Abortus Provokatus}

Abortus provokatus adalah aborsi yang disengaja baik dengan memakai obat-obatan maupun alat-alat. Aborsi provocatus merupakan istilah lain yang secara resmi dipakai dalam kalangan kedokteran dan hukum. Ini adalah suatu proses pengakhiran hidup dari janin sebelum diberi kesempatan untuk bertumbuh.

\footnotetext{
${ }^{7}$ Suryono Ekototama, dkk., Abortus Prookatus bagi Korban Perkosaan Perspektif Viktimologi, Kriminologi dan Hukum Pidana, (Yogyakarta: Uniersitas Admajaya, 2001), h.31

${ }^{8}$ Ensiklopedi Indonesia, Abortus, (Jakarta: Ikhtiar Baru, 2009), h.22

${ }^{9}$ Lilien Eka Chandra, Tanpa Indikasi Medis Ibu, Aborsi sama dengan Kriminal, Lifestyle, Mei 2006, h.10

${ }^{10}$ Suryono Ekototama, dkk., Op.Cit., h. 35

11 Lilien Eka Chandra, Loc. Cit., h.28

12 Yayasan Pengembangan Pedesaan, Kesehatan Reproduksi, (Malang: Danar Wijaya, 2014), 


\section{Faktor-faktor Penyebab Terjadinya Aborsi}

Berikut ini disebutkan beberapa faktor yang mendorong pelaku dalam melakukan tindakan aborsi, yaitu: ${ }^{13}$

a. Kehamilan sebagai akibat berhubungan di luar ikatan pernikahan

Hamil di luar nikah jelas merupakan suatu aib bagi wanita yang bersangkutan, kaluarganya maupun masyarakat pada umumnya. Masyarakat tidak menghendaki kehadiran anak haram seperti itu di dunia. Akibat adanya tekanan psikis yang diderita wanita hamil maupun keluarganya, membuat mereka mengambil jalan pintas untuk menghilangkan sumber/penyebab aib tadi, yakni dengan cara menggugurkan kandungan.

b. Ekonomi

Kondisi masyarakat yang miskin (jasmani maupun rohani) biasanya menimbulkan permasalahan yang cukup kompleks. Banyak pasangan usia subur miskin kurang memperhatikan masalah-masalah reproduksi. Mereka tidak menyadari kalau usia subur juga menimbulkan problem lain tanpa alat-alat bukti kontrasepsi. Kehamilan yang terjadi kemudian tidak diinginkan oleh pasangan yang bersangkutan dan diusahakan untuk digugurkan dengan alasan mereka sudah tidak mampu lagi membiayai seandainya anggota mereka bertambah banyak.

c. Belum mampu punya anak

Banyak pasangan-pasangan muda yang tergesa-gesa menikah tanpa persiapan terlebih dahulu. Akibatnya, hidup mereka pas-pasan, hidup menumpang mertua, dan lain sebagainya. Oleh karena itu, mereka biasanya mengadakan kesepakatan untuk tidak mempunyia anak terlebih dahulu dalam jangka waktu tertentu. Jika terlanjur hamil dan betul-betul tidak ada persiapan untuk menyambut kelahiran sang anak, mereka dapat menempuh jalan pintas dengan cara menggugurkan kandungannya. Harapannya, dengan hilangnya embrio/janin tersebut, dimasa-masa mendatang mereka tak akan terbebani oleh kehadiran anak yang tentu saja membutuhkan biaya yang tidak sedikit untuk merawatnya sampai besar dan menjadi orang.

d. Kehamilan akibat perkosaan

Perkosaan adalah pemaksaan hubungan kelamin (persetubuhan) seorang pria kepada seorang wanita. Konsekuensi logis dari adanya perkosaan adalah terjadinya kehamilan. Kehamilan pada korban ini oleh seorang wanita korban perkosaan yang bersangkutan maupun keluarganya jelas tidak diinginkan. Pada kasus seperti ini, selain trauma pada perkosaan itu sendiri, korban perkosaan juga mengalami trauma terhadap kehamilan yang tidak dinginkan. Hal inilah yang menyebabkan si korban menolak keberadaan janin yang tumbuh di rahimnya.

e. Faktor lainnya

Seperti para pekerja seks komersial, pasangan yang belum menikah dengan kehidupan seks bebas atau pasangan yang salah satu/keduanya sudah bersuami/beristri (perselingkuhan) yang terlanjur hamil atau gagal metode kontrasepsi.

\section{Dampak Aborsi}

Dalam melakukan aborsi, apa pun caranya pasti akan ada dampak aborsi tersebut, adapun dampak aborsi ilegal ada beberapa hal, yaitu: ${ }^{14}$

a. Jika dilakukan menggunakan alat-alat tidak standar dan tajam misalnya lidi, ranting pohon, atau yang lainnya, maka resiko rahim robek atau terluka.

\footnotetext{
${ }^{13}$ Yayah Chisbiyah, dkk, Kehamilan Yang Tidak Dikehendaki, (Yogyakarta: PPPK-UGM, 2006), h. $47-50$

${ }^{14}$ Sri Setyowati, Masalah Abortus Kriminalis di Indonesia dan Hubungannya dengan Keluarga Berencana Ditinjau dari Kitab Undang-Undang Hukum Pidana, (Jakarta: TP, 2002), h.68
} 
b. Rahim yang lebih dari 3 kali diaborsi beresiko jadi kering, infeksi, atau bahkan memicu tumbuhnya tumor.

c. Aborsi illegal yang dilakukan oleh orang yang tidak ahli, dapat menyebabkan proses kuretasi tidak bersih hingga menjadi pendarahan hebat.

d. Peralatan yang tidak steril akan memicu munculnya infeksi di alat reproduksi wanita, bahkan sampai ke usus.

e. Bagi pelaku, rasa berdosa yang timbul karena aborsi dapat menyebabkan mereka menderita depresi, berubah kepribadiannya jadi introvert, serta sering tak bisa menikmati hubungan seksual jika telah menikah.

f. Jika pelaku aborsi kelak hamil kembali dengan kehamilan yang diinginkan, maka kehamilan tersebut ada kemungkinan besar akan bermasalah, atau janin dapat mengalami masalah pada mata mata, otak atau alat pencernaannya.

\section{Dewasa Awal}

Istilah adult berasal dari kata kerja Latin, seperti juga istilah adolescenceadolescere yang berarti tubuh menjadi kedewasaan. Akan tetapi, kata adult berasal dari bentuk lampau kata kerta adultus yang berarti telah tumbuh menjadi kekuatan dan ukuran yang sempurna atau telah menjadi dewasa. Jadi, orang dewasa adalah individu yang telah menyelesaikan pertumbuhannya dan siap menerima kedudukan dalam masyarakat bersama dengan orang dewasa lainnya. Masa dewasa awal dimulai pada usia 18 tahun sampai 40 tahun, saat perubahan-perubahan fisik dan psikologis yang menyertai berkurangnya kemampuan reproduktif. ${ }^{15}$

a. Ciri-ciri Masa Dewasa

Masa dewasa dini merupakan periode penyesuaian diri terhadap pola-pola kehidupan baru dan harapan-harapan sosial baru. Masa dewasa adalah kelanjutan dari masa remaja, sehingga ciri-ciri masa dewasa awal tidak jauh berbeda dari masa remaja. Ciri-ciri masa dewasa awal, yaitu masa dewasa sebagai masa pengaturan, masa dewasa sebagai usia reproduksi, masa dewasa sebagai masa bermasalah, masa dewasa sebagai masa ketegangan emosi, masa dewasa sebagai masa komitmen, masa dewasa sebagai masa keterasingan sosial, masa dewasa sebagai masa perubahan nilai, sebagai masa penyesuaian diri dengan cara hidup ${ }^{16}$

\section{Pandangan Alkitab Mengenai Aborsi}

Alkitab mengisyaratkan dan menegaskan bahwa proses pertumbuhan janin bukanlah proses yang terjadi dengan sendirinya atau secara otomatis, melainkan campur tangan Allah dalam Mazmur 139:13-14. ${ }^{17}$ Dalam Kejadian 1:28 ditulis bahwa Allah memberkati mereka dan berfirman kepada mereka tentang beranakcuculah dan bertambah banyak, penuhilah bumi dan taklukkanlah itu, serta berkuasa atas segala binatang di bumi, maka terdapat ajaran di mana Allah mengajarkan kepada umat manusia bahwa anak adalah berkat.

Allah mengutuk pembunuhan orang yang tak bersalah dalam Keluaran 20:13, inti dari perintah keenam ini adalah hak untuk menentukan hidup dan mati seseorang ada di tangan Allah. Ia menciptakan dan memberikan kehidupan bagi manusia maka Dia pula yang berhak untuk mengambil kembali kehidupan itu. Oleh karena itu, manusia tidak memiliki hak untuk menentukan hidup atau mati baik bagi dirinya sendiri maupun bagi sesamanya.

${ }^{15}$ Elizabeth B. Hurlock, Psikologi perkembangan Suatu Pendekatan Sepanjang Rentang Kehidupan, (Jakarta, Erlangga: 2009), h. 246

16 Ibid, 248-251

${ }^{17}$ Rupp, Anne Neufeld, Tumbuh Kembang Bersama Anak, (Jakarta: BPK Gunung Mulia, 2009), 


\section{Konseling Pastoral}

Konseling pastoral merupakan dimensi pendampingan pastoral dalam melaksanakan fungsi yang bersifat memperbaiki yang dibutuhkan ketika orang mengalami krisis yang merintangi pertumbuhannya. Konseling pastoral berperan berperan dalam suatu krisis dan kemalangan hidup, baik individu maupun keluarga, bahkan dalam krisis perubahan social dalam masyarakat. Konseling pastoral menjadi alat penyembuhan dan pertumbuhan dengan membantu orang memperbaiki dan mengembangkan yang paling sulit yang sementara dihadapinya. ${ }^{18}$

\section{Fungsi Pendampingan Pastoral}

Adapun beberapa fungsi pendampingan pastoral merupakan tujuan-tujuan operasional yang hendak dicapai dalam memberikan pertolongan kepada orang lain, yaitu sebagai berikut: ${ }^{19}$

1. Fungsi bimbingan (guiding)

Fungsi membimbing berarti membantu konseli ketika harus mengambil keputusan di antara pilihan-pilihan yang ada karena pilihan-pilihan tersebut timbul dari relasi pastoral yang mempengaruhi keadaannya di masa sekarang dan akan datang.

2. Fungsi penopangan (sustaining)

Fungsi menopang membantu konseli untuk menerima kenyataan sebagaimana adanya, mandiri dalam keadaan yang baru, serta bertumbuh secara penuh dan utuh.

3. Fungsi penyembuhan (healing)

Fungsi menyembuhkan ini menuntun konseli mengungkapkan perasaan hatinya yang terdalam. Sebab bukan tidak mungkin secara fisik merupakan akibat dari sebuah tekanan secara psikis emosional. Melalui interaksi yang terbuka konseli dibawa pada hubungan dengan Tuhan baik melalui doa, pembacaan firman Tuhan dan percakapan pastoral.

4. Fungsi memulihkan/memperbaiki hubungan (reconciling)

Fungsi memulihkan berarti membantu konseli memperbaiki kembali hubungan yang rusak antara dirinya dan orang lain, dan menolong konseli memaafkan kesalahan yang telah dilakukan orang dan memberi mereka pengampunan.

5. Fungsi memelihara/mengasuh (nurturing)

Fungsi memelihara atau mengasuh memampukan konseli untuk mengembangkan potensi-potensi yang diberikan Allah kepadanya. Potensi yang dapat dilihat dalam proses tersebut adalah apa yang dapat ditumbuhkembangkan sebagai kekuatan dalam melanjutkan kehidupannya, sehingga mereka didorong ke arah pertumbuhan dan perkembangan secarsa holistik.

\section{Konseling Individual}

Konseling adalah suaru proses yang terjadi dalam hubungan seseorang dengan seseorang yaitu individu yang mengalami masalah yang tak dapat diatasinya, dengan seorang petugas profesional yang telah memperoleh latihan dan pengalaman untuk membantu agar klien memecahkan kesulitanya. ${ }^{20}$ Proses konseling individu berpengaruh besar terhadap peningkatan klien karena pada konseling individu konselor berusaha meningkatkan sikap klien dengan cara berinteraksi selama jangka waktu tertentu dengan cara bertatap muka secara langsung untuk menghasilkan peningkatan pada diri klien, baik cara berpikir, berperasaan, sikap, dan perilaku. ${ }^{21}$

\footnotetext{
${ }^{18}$ Engel J.D., Pastoral dan Kebutuhan Dasar Konseling, (Jakarta: BPK Gunung Mulia, 2016). h.11

${ }^{19}$ Engel J.D., Pastoral dan Kebutuhan Dasar Konseling, h.5-8

${ }^{20}$ Willis S. Sofyan, Konseling Individual Teori dn Praktek (Bandung, CV Alfabeta, 2012) h.18

${ }^{21}$ Holipah, The Using Of Individual Counseling Service to Improve Student's Learning Atitude And Habit At The Second Grade Student of SMP PGRI 6 Bandar Lampung (Journal Counseling, 2011)
} 
Tujuan umum konseling individu adalah membantu klien menstrukturkan kembali masalahnya dan menyadari life style serta mengurangi penilaian negatif terhadap dirinya sendiri serta perasaan-perasaan inferioritasnya. Kemudian membantu dalam mengoreksi presepsinya terhadap lingkungan, agar klien bisa mengarahkan tingkah laku serta mengembangkan kembali minat sosialnya. ${ }^{22}$

\section{METODOLOGI}

Penelitian ini adalah penelitian yang bersifat kualitatif. dengan pendekatan studi kasus (case study). Penelitian ini memusatkan diri secara intensif pada satu objek tertentu yang mempelajarinya sebagai suatu kasus. Data studi kasus dapat diperoleh dari semua pihak yang bersangkutan, dengan kata lain dalam studi ini dikumpulkan dari berbagai sumber. ${ }^{23}$

Penelitian studi kasus adalah penelitian yang meneliti fenomena kontemporer secara utuh dan menyeluruh pada kondisi yang sebenarnya dengan menggunakan berbagai sumber data. Dalam studi kasus, peneliti mencoba menemukan sebuah atau lebih variable penting dalam sejarah atau perkembangan objek tersebut.

\section{Sumber Data Penelitian}

Jenis data yang digunakan dalam penelitian ini, terdiri dari 2 sumber yaitu data primer dan data sekunder. Data primer adalah data yang diperoleh langsung dari sumbernya yaitu para perempuan yang melakukan aborsi, keluarga dan sebagian masyarakat di Desa Kalinaun. Sementara, data sekunder merupakan data yang tidak dilakukan secara langsung oleh peneliti, seperti buku-buku tentang layanan konseling pastoral dan buku-buku tentang aborsi.

Teknik pengumpulan data merupakan cara mengumpulkan data yang dilakukan dalam penelitian ini adalah : (1) observasi; (2) wawancara. ${ }^{24}$

\section{Teknik Analisa Data}

Dalam penelitian ini, teknil analisa datanya adalah sebagai berikut :

\section{Reduksi Data}

Reduksi data dilakukan secara berkesinambungan dari awal hingga akhir penelitian, yaitu dengan memilah dan memilih hal-hal yang penting, kemudian memfokuskan pada hal-hal tersebut, agar dapat memberikan gambaran yang jelas dan mempermudah dalam proses pengumpulan data. ${ }^{25}$

2. Display Data

Setelah menyelesaikan proses reduksi, langkah selanjutnya ialah menyajikan atau memaparkan data tersebut sebagai kumpulan informasi terstruktur yang memungkinkan untuk mengambil kesimpulan atau tindakan dalam penelitian sesuai dengan tujuan yang hendak dicapai. ${ }^{26}$

3. Penarikan Kesimpulan

Penarikan kesimpulan atau verifikasi merupakan suatu proses mencari dan mendapatkan arti dari benda-benda, mencatat keteraturan, pola konfigurasi, alur sebab akibat dan proporsisi dari peneliti. ${ }^{27}$

\footnotetext{
22 Prayitno, Konseling Perorangan (Padang, Universitas Negeri Padang, 2005) h.52

${ }^{23}$ Nawawi, Metode Penelitian Kualitatif, (Jakarta: Gramedia, 2003), h.13 h.148-151

24 Imam Gunawan, Metode Penelitian Kualitatif, Teori dan Praktik, (Jakarta: Bumi Aksara, 2013),

${ }^{25}$ Buku Panduan Penelitian Karya Ilmiah STAKN Manado (Tateli, 2013), h.37

${ }^{26}$ Ibid., h.37

27 Ibid., h.38
} 


\section{HASIL DAN PEMBAHASAN}

\section{Pemahaman Masyarakat Mengenai Aborsi}

Dalam mengetahui pemahaman masyarakat mengenai aborsi, peneliti mewawancarai salah seorang ibu rumah tangga di Desa Kalinaun. Menurutnya, tindakan aborsi adalah tindakan yang tidak terpuji jika tindakan tersebut diakibatkan adanya faktor-faktor yang mendorong pelaku melakukan aborsi, walaupun ada juga tindakan aborsi di rumah sakit bisa dibilang demi kebaikan karena ada perempuanperempuan yang lain sedang bermasalah dengan kandungannya atau rahim yang mengharuskan melalukan aborsi, tapi ia juga mengatakan bahwa di dunia yang zaman sekarang, yang paling aborsi dilakukan karena hamil di luar nikah yang dianggap sebagai membuat malu keluarga yang ada, bahkan keluarga juga membantu dalam tindakan aborsi yang akan dilakukan karena saat itu mereka berpikir bahwa tidak ada pilihan lain selain melakukan aborsi. Menurutnya, di setiap desa-desa harus ada sosialisasi pergaulan bebas, tentang bagaimana dampak dari berhubungan seks di luar nikah dan di bawah umur, dan pengawasan orang tua bagi anak-anaknya, sehingga tidak terjadi kehamilan yang berujung dengan tindakan aborsi.

2. Wawancara Subjek Penelitian

a. Subjek I

Pada kasus pertama ini, menurut penuturan subjek bahwa pertama kali subjek melakukan aborsi dengan usia kandungan 3 bulan pada bulan Desember 2017 karena sedang bekerja di sebuah perusahaan yang tidak bisa menerima wanita hamil untuk bekerja dan karena pada saat itu suami subjek sedang bekerja di kapal sehingga subjek juga berpendapat bahwa ia tidak mampu mengurus anak lagi jika suami hanya bisa pulang 2 kali dalam setahun. Subjek melakukan aborsi dengan meminum obatobat herbal dari seorang yang bisa disebut bidan kampung. ${ }^{28}$

Tindakan aborsi kedua dilakukan menurut subjek pada bulan Juni 2018 dengan usia kandungan 6 bulan karena saat itu lelaki yang menghamili subjek tidak mengakui bahwa anak dalam kandungan subjek itu adalah anaknya, saat itu pun dipikiran subjek hanya terlintas jalan keluar dengan cara mengaborsi kandungan tersebut. Setelah melakukan aborsi itu, menurut subjek ia harus menjalani perawatan dokter karena aborsi yang dilakukannya mengalami pendarahan, saat itu pun badan subjek semakin terlihat kurus.

Pada aborsi yang ketiga subjek mengatakan bahwa ia menggugurkan kandungannya yang berusia 5 bulan pada bulan Maret 2019 karena belum siap untuk berumah tangga dan masih ingin kuliah karena saat itu subjek sedang menjalani pendidikan dengan dana beasiswa dari perusahaan di desa, pada waktu itu juga pacarnya sudah siap untuk bertanggung jawab dan ingin menikahi subjek. Kemudian subjek menggugurkan kandungannya tanpa sepengetahuan pacarnya dan tidak masuk kampus selama 2 bulan sehingga kuliah pun ikut terhenti, dan hubungan subjek juga sudah tidak berlanjut lagi. Saat setelah tindakan aborsi tersebut, subjek hanya menjalani perawatan herbal di rumah kakaknya.

Pada bulan Juni lalu subjek mengatakan bahwa subjek sempat kejang-kejang dan jatuh dan tidak sadarkan diri tapi hanya diobat dengan obat herbal sampai subjek sadar dan di bawah di Polindes untuk diperiksa, bidan memeriksa bahwa darah subjek 80/60 dan mungkin karena pengguguran yang dilakukan subjek, bidan memberi saran bahwa subjek harus periksa langsung ke rumah sakit tapi subjek tidak mau.

\section{b. Kakak Subjek I}

${ }^{28}$ Wawancara Sabtu 29 Juni 2019 subjek 1 (rini) 
Ketika ditanya mengenai perilaku subjek, kakak subjek mengatakan bahwa subjek sudah tidak baik di mata masyarakat karena subjek yang sudah berusia 26 tahun selalu berpakaian yang serba terbuka di depan umum, belum lagi ada sebagian masyarakat yang mengetahui tindakan aborsi yang dilakukan subjek, bahkan sekarang menjalani hubungan gelap dengan lelaki yang berstatus suami orang yang sampai menimbulkan perselisihan antara keluaga subjek dan istri serta keluarga dari lelaki tersebut. ${ }^{29}$

Kakak subjek berharap subjek bisa kembali ke perilaku dan kehidupan yang lebih baik lagi, karena menurut kakak subjek, setelah tindakan-tindakan aborsi yang dilakukan subjek, subjek akan belajar dari pengalaman itu untuk tidak mengulanginya lagi. Pada terakhir kali kakak subjek melihat subjek yang kejang-kejang dan pingsan, kakak subjek mengatakan bahwa ia lebih kasihan melihat ayah subjek yang sudah semakin tua dan sambil menangis melihat subjek yang sedang kesakitan.

\section{c. Subjek II}

Pada kasus kedua ini berdasarkan hasil wawancara subjek, subjek melakukan aborsi karena takut pada keluarganya apalagi ayah subjek, karena itu subjek tidak pulang ke rumah dan hanya tinggal di kos-kosan. Kandungan subjek saat melakukan aborsi itu sudah memasuki usia 3 bulan karena setelah mengetahi kehamilannya, subjek belum mempunyai uang untuk membeli obat di sebuah apotik dekat rumah sakit dengan harga 650 ribu. Subjek memakai uang dari uang yang diberikan ibu subjek untuk membayar kos-kosan selama 2 bulan (500 ribu/bulan), sisa dari membeli obat tersebut subjek pakai untuk membeli makanan dan minuman serta vitamin untuk mengembalikan kondisi kesehatan subjek setelah melakukan aborsi. ${ }^{30}$

Setelah kesehatan subjek mulai membaik, subjek masih merasa takut untuk pulang ke rumah karena masih takut jika akan ketahuan kalau subjek telah hamil dan melakukan aborsi, subjek juga tidak masuk kuliah selama 2 bulan dan sudah ketinggalan mata kuliah jadi subjek harus mengontrak kembali mata kuliah di tahun depan. Untuk menghindari agar orang tua subjek tidak mengetahui tindakan aborsi tersebut, subjek kadang pulang ke rumah dan berusaha mencari alasan yang berkaitan dengan kegiatan kampus agar tidak bisa pulang. Saat pulang pun subjek selalu mencari kesempatan agar tidak duduk bersama dengan orang tuanya, tapi subjek mengatakan kepada peneliti bahwa subjek akan berusaha menjadi anak yang baik di mata orang tuanya dan kakaknya serta adiknya.

\section{d. Ibu Subjek II}

Menurut ibu subjek, subjek adalah anak gadis yang sudah berusia 18 tahun yang sangat pendiam di antara kakak dan adiknya, paling banyak subjek melakukan berbagai hal di rumah tapi jarang juga mengeluarkan suara. Waktu beberapa bulan lalu, ayah subjek mengetahui kalau subjek sudah tidak aktif dalam perkuliahan dan uang kos-kosan pun tidak dibayar, ayah subjek kemudian mabuk-mabukan dan sampai di rumah ia memarahi subjek dan hampir memukul subjek, setelah ditanya subjek hanya diam saja, ibu subjek dan ayah bahkan kakak subjek pun tidak memaksa subjek untuk mengatakan alasannya kenapa sampai ia tidak mengukuti perkuliahan dan uang kos dipakai untuk apa. ${ }^{31}$

Ibu subjek mengatakan, orang tua juga tidak harus memaksa jika subjek harus mengatakan semua tentang urusan subjek, ibu subjek pun menyesuaikan keadaan yang ada dan mengatar subjek ke kos-kosan dan membayar uang kos-kosan.

\footnotetext{
${ }^{29}$ Wawancara 30 Juni 2019 kakak subjek (Ranti)

${ }^{30}$ Wawancara 05 Juli 2019 Subjek 2 (Bunga)

31 Wawancara 06 Juli 2019 ibu subjek (Lani)
} 
Menurut ibu subjek, subjek sekarang sudah mulai aktif lagi di kampus dan ibu subjek berharap subjek tidak mengulangi kesalahannya lagi.

e. Kakak Subjek II

Berdasarkan wawancara pada kakak subjek, subjek dan kakaknya tidak terlalu dekat karena menurut kakaknnya, subjek adalah anak yang selalu berbohong dalam banyak hal. Semenjak subjek bersekolah di SMK Bitung, dari situlah kakak subjek menyadari kalau subjek mulai berbohong pada kakaknya bahkan kepada orang tuanya. Setelah subjek mulai kuliah, kakak subjek merasa sudah tidak tahan dengan perilaku subjek yang sering berbohong kepada orang tua, apalagi masalah uang. Ada juga beberapa teman subjek yang menghubungi kakak subjek untuk mengetahui keberadaan subjek, karena ada berbagai hal seperti uang yang dipinjam oleh subjek, pakaian dan sepatu yang dipinjam subjek bahkan sampai tidak memberitahu tentang barang-barang tersebut pada temannya. ${ }^{32}$

Kakak subjek mengatakan, walalupun mereka berbeda ayah, kakak subjek tetap mempunyai rasa sayang kepada subjek yang kadang dimarahi oleh ayah subjek hanya karena masalah yang sama yaitu berbohong. Kakaknya juga pernah mengatakan kepada subjek, bila ada sesuatu yang subjek inginkan, cobalah bicara dan minta dengan baik-baik daripada harus berbohong yang pada akhirnya hanya membuat ayah subjek marah kepada subjek.

\section{Observasi}

\section{a. Keluarga Subjek I}

Dari proses observasi, peneliti melihat bahwa kondisi keluarga subjek begitu harmonis, hanya saja waktunya dalam bersama keluarga yang kurang karena paling banyak subjek di luar rumah. Subjek dan ayahnya tinggal serumah dengan kakak tertua yang mempunyai suami dan 2 orang anak. Proses komunikasi subjek dengan keluarga juga begitu baik, itu terlihat saat mereka duduk di rumah maupun di pantai ketika sedang menunggu kakak kedua subjek pulang dari mencari ikan. Subjek dan keluarganya juga sering makan bersama walaupun tidak duduk semeja, hanya saja makanan yang diatur di meja dan subjek beserta keluarga hanya mengambil makanan dan duduk terpisah dari dapur hingga ruang tamu, tapi komunikasi dan saling bercanda saat makan pun tetap ada.

\section{b. Subjek I}

Berdasarkan yang diamati oleh peneliti, subjek mempunyai postur tubuh yang kecil tapi tinggi, berambut pirang, berbadan kurusan dan mempunyai tato di belakang leher. Subjek paling banyak berada di rumah temannya daripada di rumah, tapi ketika subjek di rumah subjek yang akan memasak makanan pada pagi hari dan siang bahkan sampai malam subjek di rumah temannya. Setiap harinya subjek selalu memakai pakaian yang serba terbuka, bahkan sering juga memakai celana panjang yang robekrobek.

Pada malam hari subjek biasanya biasanya mencari kesempatan untuk bertemu dengan seorang pria yang berstatus suami orang. Walaupun subjek juga sudah pernah menikah, perilaku subjek masih seperti anak muda lainnya yang sering nongkrong di pinggir jalan dengan teman-temannya pada saat malam. Subjek juga sering minum minuman beralkohol katika ada pesta yang berlangsung malam bahkan sampai pagi.

\section{c. Keluarga Subjek II}

Berdasarkan hasil observasi peneliti, keluarga subjek ini tidak terlihat baikbaik saja karena ayah subjek yang terlalu otoriter kepada subjek, kakak subjek bahkan adik subjek. Selama subjek dalam menjalani pendidikan sebagai mahasiswa, ayah dan

\footnotetext{
${ }^{32}$ Wawancara 06 Juli 2019 kakak subjek (Elin)
} 
kakak subjek yang bekerja, ibu subjek yang adalah perangkat desa, dan adik subjek yang masih di bangku SD, pertemuan keluarga pun paling banyak di waktu malam dan di waktu hari sabtu dan minggu, bahkan subjek lebih memilih untuk pulang ke rumah 3 minggu sekali. Subjek juga hampir selalu bertengkar dengan kakaknya yang membuat ayah subjek selalu menghukum dengan tidak boleh keluar rumah. Subjek terlihat lebih dekat dengan ibu subjek.

Subjek juga terlihat lebih pendiam jika bersama dengan keluarga, hanya akan berkata-kata ketika peneliti duduk bersama dengan subjek dan keluarga subjek atau jika dengan orang lain yang selalin peneliti. Walaupun demikian, dalam beribadah, keluarga ini sangat amat rajin setiap ibadah minggu maupun ibadah kebaktian di rumah-rumah keluarga. Ibu subjek bahkan ikut serta dalam ibadah puasa hampir setiap harinya.

d. Subjek II

Subjek mempunyai postur tubuh yang kecil, kulit hitam dan berbadan pendek. Subjek yang kesehariannya jika di rumah paling banyak main handphone dan nonton tv atau bersantai di rumah temannya. Tapi jika subjek berada di kos-kosan, subjek lebih banyak di kamarnya dan hanya pergi ke kamar temannya jika membuat tugas atau meminta keperluan lainnya. Di kampus juga subjek kurang bergaul dengan teman-temannya bahkan dalam sekelas. Ada beberapa teman-teman subjek yang sudah dekat dengan subjek, tapi semuanya pasti akan menimbulkan masalah dengan subjek yang bisa sampai tidak saling menegur dengan teman-temannya.

\section{Pembahasan}

Berdasarkan dari teori yang ada mengenai faktor-faktor terjadinya aborsi, seperti akibat hubungan di luar pernikahan, belum mampu punya anak, faktor ekonomi, anak sudah cukup banyak, kehamilan akibat perkosaan, dan faktor-faktor lainnya seperti karena hubungan perselingkuhan. ${ }^{33}$ Maka faktor-faktor penyebab terjadinya aborsi dari subjek I lewat penelitian ini bukan karena kepentingan bersama pasangan mereka atau karena dorongan dari orang lain melainkan karena kepentingan diri sendiri atau atas kemauan sendiri yang merasa belum mampu punya anak dan kehamilan akibat dari hubungan di luar ikatan pernikahan. Peneliti menemukan bahwa setelah melakukan aborsi, subjek tidak belajar dari pengalaman yang ada dan lebih menjadikan pengalaman itu sebagai peluang untuk melakukan aborsi jika kehamilan karena kelalaian terjadi lagi. Itu sebabnya perilaku subjek masih tidak menunjukkan perilaku yang baik dimata keluarga dan masyarakat. Bahkan subjek yang dengan fisik yang terlihat kurus akibat aborsi, dan subjek mengalami kejang-kejang sampai tidak sadarkan diri, dokter memriksa bahwa kemungkinan subjek mengalami infeksi pada rahim yang diakibatkan oleh tindakan aborsi yang beberapa kali.

Alasan utama subjek II karena subjek yang sedang menjalani pendidikan dan karena adanya ketakutan terhadap ayah subjek yang terlalu otoriter sehingga membuat subjek kesulitan untuk menyampaikan sesuatu yang penting kepada orang tuanya. Subjek yang lebih pendiam sehingga kurang juga keinginan untuk dekat dengan teman-temannya dan subjek lebih suka berdiam diri di kamar.

Dalam tindakan aborsi, pasti akan ada dampak negatif bagi mereka yang melakukan aborsi, seperti dampak aborsi yang berdasarkan teori dari Sri Setyowati mengenai dampak aborsi, bahwa aborsi akan memberi dampak pada kesehatan subjek yang bisa saja tidak bisa memiliki anak kembali di kemudian hari karena sudah 3 kali melakukannya dan mengakibatkan rahim menjadi kering, infeksi bahkan bisa memicu

${ }^{33}$ Yayah Chisbiyah, dkk, Kehamilan Yang Tidak Dikehendaki, (Yogyakarta: PPPK-UGM, 2006), 
tumor. ${ }^{34}$ Tindakan aborsi juga memberi dampak pada subjek yang memiliki ketakutan akan terjadi hal tidak diinginkan jika harus duduk bersama dengan orang tuanya.

Berdasarkan teori yang ada mengenai dewasa awal, para subjek sudah masuk pada usia masa dewasa awal 18 tahun sampai 40 tahun, di mana para subjek sudah berusia 20 dan 26 tahun yang sudah bisa menerima tanggung jawab sebagai ibu dan pengurus rumah tangga, bahkan masa dewasa awal adalah masa di mana subjek disibukkan dengan berbagai masalah yang berhubungan dengan penyesuaian diri dalam kehidupan orang dewasa. Subjek juga yang dalam ketegangan emosionalnya terdapat ketakutan atau kekhawatiran dalam menghadapi persoalan dalam keluarganya jika mengetahui tindakan aborsi dilakukan para subjek.

Dalam penelitian ini peneliti memakai teknik konseling individual untuk membuat rancangan intervensi yang berdasarkan teori tentang konseling individual yaitu membantu individu yang mengalami masalah yang tak dapat diatasinya, dengan seorang petugas profesional yang telah memperoleh latihan dan pengalaman untuk membantu agar klien memecahkan kesulitanya. ${ }^{35}$

\section{Rancangan Intervensi yang Disarankan}

Dalam proses intervensi ini dengan tujuan mengubah perilaku yang negatif dan membantu klien pemikiran negatif dari subjek, peneliti memakai teknik konseling individual dalam melakukan pendampingan terhadap subjek yang melakukan tindakan aborsi. Pendampingan pastoral diadakan dengan 6 sesi sesuai dengan fokus dan target intervensi sebagai berikut.

a. Fokus Intervensi

1) Subjek : Konseling Individual

2) Keluarga : Konseling Keluarga

b. Target Intervensi

1) Subjek

Mengubah perilaku negatif subjek dan mengubah pemikiran subjek dengan realita yang ada agar mampu dan berani menghadapi kenyataan yang ada. Tujuan ini juga mengandung makna bahwa klien haruslah dapat berubah dari ketergantungan lingkungan yang negatif, dan dapat berbuat lebih banyak untuk meningkatkan kebermaknaan hidup mereka, dan bisa mencapai kesadaran atas apa yang mereka lakukan.

2) Keluarga

Kiranya keluarga mampu membuat subjek memahami dan mengerti dengan tindakan yang dilakukan subjek. Kiranya juga keluarga dapat mendorong subjek untuk berubah ke arah yang lebih baik, dan memahami pentingnya komunikasi dan kebersamaan antar keluarga.

c. Pelaksanaan Pendampingan

Pendampingan yang akan dilakukan untuk subjek, selama 6 kali pertemuan dengan jadwal pertemuan sekali dalam seminggu. Pendampingan yang dilakukan dengan durasi waktu dalam setiap pertemuan antara 50-60 menit. Untuk keluargakeluarga subjek diberikan pendampingan dengan 3 sesi untuk setiap keluarga subjek dan berjangka waktu 20-30 menit. Berikut adalah table pendampingan terhadap subjek dan keluarga subjek.

${ }^{34}$ Sri Setyowati, Masalah Abortus Kriminalis di Indonesia dan Hubungannya dengan Keluarga Berencana Ditinjau dari Kitab Undang-Undang Hukum Pidana, (Jakarta: TP, 2002), h.68

${ }^{35}$ Willis S. Sofyan, Konseling Individual Teori dn Praktek (Bandung, CV Alfabeta, 2012) h.18 


\section{E. PENUTUP}

Kesimpulan yang dapat peneliti berikan terhadap apa yang peneliti teliti mengenai kasus perempuan yang melakukan aborsi adalah sebagai berikut.

1. Masyarakat Desa Kalinaun memahami bahwa tindakan aborsi merupakan tindakan yang tidak benar di mata manusia dan Tuhan Allah, karena tindakan tersebut merupakan tindakan pembunuhan. Meskipun ada beberapa kasus yang ditemui masyarakat bahwa aborsi dilakukan demi menyelamatkan nyawa sang ibu karena dengan berbagai alasan medis, tapi tetap ada rasa bersalah dari seorang ibu jika harus kehilangan anaknya. Tapi bagi mereka yang melakukan aborsi dengan disengajakan, mereka bisa saja tidak memiliki rasa bersalah.

2. Faktor yang mendorong tindakan aborsi dari para perempuan di Desa Kalinaun yaitu adanya kegoisan dari para perempuan atau tindakan aborsi dilakukan karena keinginan sendiri, seperti karena masih belum mampu mengurus dan masih tidak ingin memiliki anak serta masih ingin melanjutkan jenjang pendidikan. Kurangnya komunikasi antara anggota keluarga juga menjadi faktor yang mempengaruhi tindakan aborsi yang dilakukan oleh para perempuan di Desa Kalinaun.

3. Setelah melakukan aborsi, fisik para perempuan yang melakukan aborsi terlihat lebih kurus dari sebelum mereka melakukan aborsi, subjek mengalami kejang-kejang yang hasil pemeriksaannya diakibatkan karena adanya infeksi pada rahim. Subjek yang lainnya mengalami ketakutan terhadap ayahnya, sehingga subjek sulit dalam berkomunikasi dengan ayahnya, subjek lebih menjadi anak yang pendiam dan lebih suka berdiam diri di kamar.

4. Rancangan konseling yang akan dilaksanakan adalah Konseling Individual, di mana bertujuan untuk membantu para perempuan yang melakukan aborsi mengubah perilaku negatif dan membantu para perempuan mengoreksi presepsinya terhadap lingkungan, terlebih menghilangkan pemikiran-pemikiran negatif yang mempengaruhi tingkah laku. Di dalamnya juga yang membimbing para perempuan dengan ayat-ayat Alkitab, bahwa apa yang mereka lakukan tidak dibenarkan oleh Tuhan Allah.

Adapun saran yang akan diberikan oleh peneliti terhadap subjek, Desa Kalinaun, dan tokoh-tokoh agama sebagai berikut.

1. Subjek

Kiranya subjek yang melakukan aborsi dapat mengerti dan memahami mengenai pendekatan peneliti terhadap subjek, dan kiranya mengubah hal-hal yang negatif menjadi hal yang positif dan tidak lagi melakukan aborsi karena bisa merusak kesehatan dari subjek dan merusak nama baik subjek dan keluarga.

\section{Desa Kalinaun}

Kiranya pemerintah dapat melaksanakan sosialisasi kepada masyarakat terlebih anakanak muda dalam menjalani pergaulan yang bai bagi anak muda sekarang. Dapat membuat program dengan melibatkan tokoh-tokoh agama dalam melakukan konseling apabila ada anggota masyarakat yang melakukan aborsi.

3. Gereja

Kiranya Gereja lebih memperhatikan setiap jemaat, bukan hanya ketika jemaat yang menyampaikan jika ada pergumulan tapi ketika diketahui ada anggota jemaat yang melakukan aborsi, kiranya Gereja dapat membimbing para jemaat ke jalan yang benar dalam menghadapi masalah sesuai jalan yang dikehendaki Tuhan Allah.

4. Konselor yang akan Melakukan Intervensi

a. Kiranya konselor mampu membangun hubungan konseling dengan konseli, karena keberhasilan proses konseling amat ditentukan oleh keberhasilan pada tahap awal 
konseling, dimana harus ada keterbukaan dari konselor, tidak berpura-pura, mengerti, menghargai konseli dan harus menjaga kerahasiaan dari konseli.

b. Setelah konseling dilaksanakan, kiranya konselor dapat memonitoring atau pengawasan kepada konseli, agar dapat diketahui hasil dari pelaksanaan konseling terhadap konseli.

\section{DAFTAR PUSTAKA}

Anne Neufeld Rupp, Tumbuh Kembang Bersama Anak, (Jakarta: BPK Gunung Mulia, 2009)

Chandra Lilien Eka, Tanpa Indikasi Medis Ibu, Aborsi sama dengan Kriminal,Lifestyle, Mei 2006

Chisbiyah ddk, Yahya, Kehamilan Yang Tidak Dikehendaki, (Yogyakarta: PPPK-UGM, 2006)

Echols, dan Hassan Shaddily, Kamus Inggris Indonesia, (Jakarta: Gramedia, 2014)

Engel J.D., Pastoral dan Kebutuhan Dasar Konseling, (Jakarta: BPK Gunung Mulia, 2016)

Frans Sadewo, Kejadian Keguguran, Kehamilan Tidak Direncanakan dan Pengguguran di Indonesia, (Surabaya: Akademia, 2017)

Gunawan Imam, Metode Penelitian Kualitatif, Teori dan Praktik, (Jakarta: Bumi Aksara, 2013)

Holipah, The Using Of Individual Counseling Service to Improve Student's Learning Atitude And Habit At The Second Grade Student of SMP PGRI 6 Bandar Lampung (Journal Counseling, 2011)

Hurlock Elizabeth B., Psikologi perkembangan Suatu Pendekatan Sepanjang Rentang Kehidupan, (Jakarta, Erlangga: 2009)

Nawawi, Metode Penelitian Kualitatif, (Jakarta: Gramedia, 2003)

Prayitno, Konseling Perorangan (Padang, Universitas Negeri Padang, 2005)

Setyowati Sri, Masalah Abortus Kriminalis di Indonesia dan Hubungannya dengan Keluarga Berencana Ditinjau dari Kitab Undang-Undang Hukum Pidana, (Jakarta: TP, 2002)

Sofyan Willis S., Konseling Individual Teori dan Praktek (Bandung, CV Alfabeta, 2012)

Soge Paulinus, Hukum Aborsi Tinjauan Politik Hukum Pidana Terhadap Perkembangan Hukum di Indonesia, (Yogyakarta: Universitas Atmajaya, 2010) 
POIMEN: Jurnal Pastoral Konseling Vol. 1, No.1, pp. 12- 26, Juni 2020 